2. Икоева Л.П., Хаева О.Э., Бацазова Т.М. Разработка элементов технологии возделывания амаранта в условиях предгорной зоны РСО-Алания // Известия Горского государственного аграрного университета. 2017. Т. 54. № 3. С. 19-24.

3. Мамиев Д.М., Абаев А.А., Шалыгина А.А. Эффективность гербицидов и минеральных удобрений на посевах кукурузы в горной зоне РСО-Алания //Известия Горского государственного аграрного университета. 2013. Т. 50. № 3. С. 26-29.

4. Мамиев Д.М., Абаев А.А., Шалыгина А.А. Усовершенствованная структура посевных площадей и севооборотов для предгорной зоны РСО-Алания// Известия Горского государственного аграрного университета. 2014. Т. 51. № 1. С. 32-36.

5. Тедеева А.А., Абаев А.А., Хохоева Н.Т. Продуктивность чины посевной в зависимости от сроков и норм высева в условиях предгорной зоны РСО-Алания // Вестник АПК Ставрополья. 2016. № 2 (22). C. 232-234.

\title{
Галстян Н.В. \\ Обзор методов исследования строения и функционирования головного отдела ЦНС
}

Северо-Осетинский государственный университет имени К.Л Хетагурова doi: $10.18411 / \mathrm{j}-05-2021-29$

(Россия, Владикавказ)

\section{Аннотация}

На сегодняшний день наука и техника находятся на таком прогрессивном этапе развития, что порой кажется, что неизученных вопросов нет и быть не может. Однако это далеко не так. Несмотря на все успехи в развитии современных технологий и науки, на массу исследований и затраченных на это средств, вопросы строения и функционирования мозга так и остались не до конца изученными и разобранными людьми.

Ключевые слова: наука, прогресс, технологии, мозг, человек.

\section{Abstract}

Today science and technology are at such a progressive stage of development that sometimes it seems that there are no unexplored questions and cannot be. However, this is not the case. Despite all the successes in the development of modern technologies and science, for the mass of research and funds spent on this, the issues of the structure and functioning of the brain have not yet been fully studied and analyzed by people.

Keywords: science, progress, technology, brain, man.

Мозг - крайне удивительный орган, привлекавший внимание ученых и философов с древних времён. По сегодняшний день финансируются крупные проекты, направленные на изучение мозга, мозговой активности. Но проблема в том, что человеческий мозг - это самый сложный из всех известных нам физических объектов во Вселенной. Об этом свидетельствует то, что в человеческом мозге находится около 96 миллиардов нейронов 10000 различных типов, каждый из которых функционирует как крошечный компьютер или микропроцессор.

Методы исследования функций ЦНС делятся на две группы:

1) непосредственное изучение;

2) опосредованное (косвенное) изучение.

Методы непосредственного изучения функций ЦНС подразделяют на морфологические (макроанатомическое и микроскопическое исследования строения мозга) и функциональные (разрушение и раздражение структур ЦНС, стереотаксический метод, электрофизиологические методы.).

К функциональным методом относят:

Метод разрушения - здесь происходит повреждение обширных участков мозговой ткани. 
Метод раздражения структур мозга позволяет установить пути распространения возбуждения от места раздражения к органу или ткани, функция которых при этом изменяется.

Стереотаксический метод введения электродов Заключается в том, что животному вводят в подкорковые структуры электрод, с помощью которого можно раздражать, разрушать, или вводить химические вещества. Тем самым животное готовят для хронического эксперимента. После выздоровления животного применяют метод условных рефлексов.

Если представить себе работу нейрона, который связан с тысячами других нейронов, мы получим крайне сложную развитую систему. Также любопытным является тот факт, что наш мозг использует в 10 раз больше кислорода, чем все остальные части тела вместе взятые. Кроме того, мозг вырабатывает примерно столько же электричества, сколько требуется для включения лампочки в 20 Вт. А для простого распознавания геометрической формы наш мозг задействует около 25 миллионов нервных клеток

\section{Клинические методы}

Клинические методы позволяют объективно оценить сенсорные функции мозга, состояние проводящих путей, способность мозга к восприятию и анализу стимулов, а также выявить патологические признаки нарушения высших функций коры больших полушарий.

Электроэнцефалография относится к наиболее распространенным электрофизиологическим методам исследования ЦНС

При малейшем привлечении внимания к стимулу развивается десинхронизация ЭЭГ, то есть развивается реакция блокады $\alpha$ - ритма.

Микроэлектродный метод - Регистрация электрических процессов в отдельных нервных клетках. Микроэлектроды - стеклянные или металлические.

Основные рефлекторные центры нервной системы

К Основным рефлекторным центрам нервной системы относится:

- Спинной мозг - Распределение функций входящих и выходящих волокон спинного мозга подчиняется определенному закону: все чувствительнье (афферентнье) волокна входят в спинной мозг через его задние корешки, а двигательные и вегетативные (эфферентные) выходят через передние корешки;

- Продолговатый мозг и варолиев мост. Продолговатый мозг и варолиев мост относят к заднему мозгу. Он является частью ствола мозг;

- Средний мозг. Через средний мозг, являющийся продолжением ствола мозга;

- Промежуточный мозг;

- Подкорковые узлы;

- Мозжечок.

$$
* * *
$$

1. Анатомия и физиология центральной нервной системы: рабочая тетрадь/ сост. О.В.Папафилова; РАНХиГС, Сиб. ин-т упр.-Новосибирск: Изд-во СибАГС, 2016.-112c

2. Е.В. Брызгалина. Концепции современного естествознания. М., Проспект, 2016.

3. «Мозг - самый жирный орган»: https://www.miloserdie.ru/article/mozg-samyj-zhirnyj-..

4. Нейрофизиология : учеб. пособие / О. И. Дорогина ; М-во науки и высш. образования Рос. Федерации, Урал. федер. ун-т. — Екатеринбург : Изд-во Урал. ун-та, 2019. — 100 с. 